\title{
NEW RECORDS OF THE MEDITERRANEAN LAND SNAIL MASSYLAEA VERMICULATA (O. F. MÜLLER, 1774) IN HUNGARY AND SLOVAKIA
}

\author{
BARNA PÁLl-GERGELY ${ }^{1}$ ZOLTÁN FEHÉR², TOMÁŠ ČEJKA ${ }^{3 *}$
}

\begin{abstract}
${ }^{1}$ Plant Protection Institute, Centre for Agricultural Research, Herman Ottó Street 15, Budapest, H-1022, Hungary (e-mail: pallgergely2@gmail.com); (1) https://orcid.org/0000-0002-6167-7221

${ }^{2}$ Department of Zoology, Hungarian Natural History Museum, H-1088 Baross u 13, Budapest, Hungary (e-mail: feher.zoltan@nhmus.hu); (1) https://orcid.org/0000-0002-4888-1156

${ }^{3}$ Institute of Botany, Plant Science and Biodiversity Center, Slovak Academy of Sciences, Dúbravská cesta 9, SK-84523 Bratislava, Slovakia (e-mail: t.cejka@gmail.com); (i) https://orcid.org/0000-0002-6485-5660 *corresponding author
\end{abstract}

ABSTRACT: The Mediterranean Massylaea vermiculata (O. F. Müller) is reported from Slovakia for the first time (two sites), and from Hungary for the first time since the 1980 record. There is a reason to suspect the existence of further, yet undetected, specimens or even populations in Central Europe. Based on the dynamics of similar invasions of terrestrial molluscs, we expect that in 2-3 decades the species may become locally abundant and widespread in both the Hungarian and the Slovak capitals.

KEY WORDS: introduced species; alien species; non-indigenous species; overwintering

For the last three decades Central Europe has experienced an increasing number of invasions of terrestrial animals, particularly molluscs (snails and slugs). In that period, 15 non-native terrestrial mollusc species have been reported in the Czech Republic, more than half of them probably of Mediterranean origin, indicating that Southern Europe is among the most frequent sources of species introduced to Central Europe (PELTANOVÁ et al. 2012). To provide further information on land snail invasions from southern countries, we report on a new Hungarian and two new Slovak occurrences of Massylaea vermiculata $(\mathrm{O}$ F. Müller, 1774) (formerly Eobania vermiculata, see BOUAZIZ-YAHIATENE et al. 2012) (Fig. 1), a species indigenous to the Mediterranean Basin. Its native range extends from Spain to Turkey, it includes the Crimean Peninsula (Welter-SChUltes 2012) and the north African coastal area.

We report on $M$. vermiculata from the following Slovak and Hungarian sites:
1. Slovakia: Bratislava City, $48^{\circ} 09.08^{\prime} \mathrm{N}, 17^{\circ} 01.87^{\prime} \mathrm{E}$, 15th June 2019, J. ČAPKA leg., horticultural facility situated next to the Danube river branch, south of it; a single snail was found on a water supply shaft (Fig. 2). The specimen is deposited in the private collection of T. Čejka.

2. Slovakia: Stupava Town, $48^{\circ} 15.70^{\prime} \mathrm{N}, 17^{\circ} 01.81^{\prime} \mathrm{E}$, 9th May 2020, D. ČEJKOVÁ leg., horticultural facility, one individual was found on lavender imported from Italy. The specimen is deposited in the private collection of T. Čejka.

3. Hungary: Budapest, District XIX, Kós Károly tér [square]: single specimen found in a yard of a house, $47^{\circ} 27.28^{\prime} \mathrm{N}, 19^{\circ} 07.59^{\prime} \mathrm{E}$, March 2020, J. KeLEMEN leg. (Fig. 3). The specimen is deposited in the Mollusca Collection of the Hungarian Natural History Museum.

Both Slovak sites are located in horticultural areas. The horticultural centre in Bratislava (area $0.4 \mathrm{ha}$ ) specialises in direct import of exotic woody plants, 
which are kept in pots and evenly distributed within the complex. The area is partly covered with geotextiles and wooden planks to prevent growth of weeds. The site is next to a flowing Danube branch (approx. $30 \mathrm{~m}$ ), which is lined with a narrow strip of floodplain forest.

The horticultural centre in Stupava is smaller (0.14 ha in area), both herbaceous and woody plants displayed are from domestic sources and from the Mediterranean region (especially from Italy). The plants are kept either in pots or in containers filled with horticultural substrate. The complex is located in a built-up area, isolated from natural habitats, adjacent only to home gardens.

The Hungarian specimen was photographed by a citizen scientist (Julianna Kelemen), who uploaded the photos to www.fajbook.hu - a citizen science webpage on which members compete on the number of animal species they have photographed. Each taxon has an expert editor who confirms or corrects the identification provided by the citizen scientists. The editor of Mollusca is one of the authors (Zoltán Fehér), who recognised the value of the observation. The single specimen was photographed at Kós Károly tér [square] in Budapest, on a wall of a condominium building. During targeted search, the photographed specimen was re-found and collected ca. two months after the photograph was taken.

The Slovak records represent the first documented occurrences in that country. In Hungary, however, the species was reported before. An amateur collector, Lajos Ottó, found six live specimens in 1979 in Lipót village, north-western Hungary, near the Slovak border (OTTÓ 1980, CSÁNYI \& VARGA 2017). He explained the survival of the snails by the character of the site. Namely, the snails were found near a wall of a greenhouse, in which hot water pipes run, and probably kept the wall and its immediate surroundings

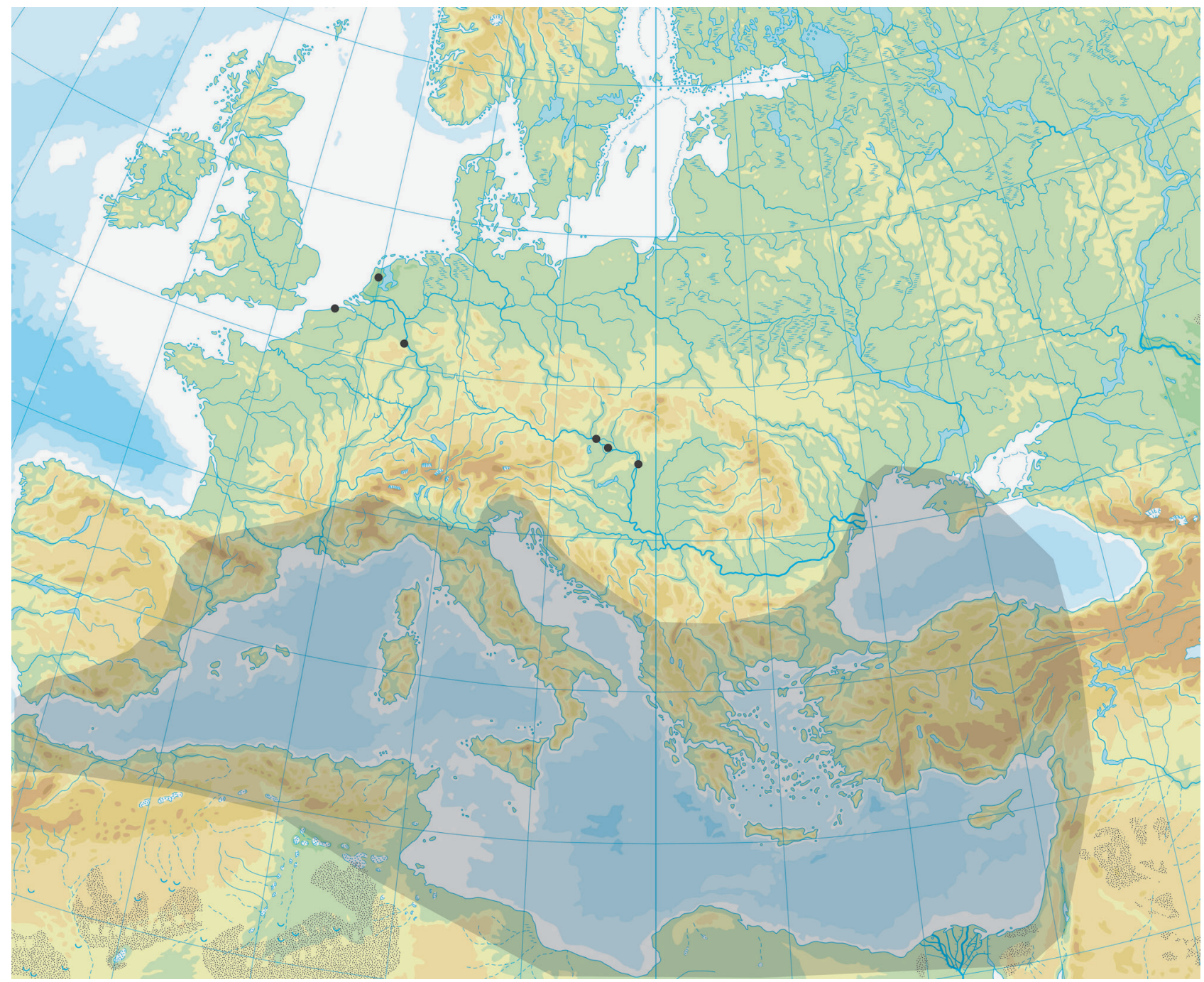

Fig. 1. Distribution of Massylaea vermiculata. Shaded area outlines the Mediterranean range of the species, where it is sometimes difficult to make distinction between native and non-native areas according to WELTER-SCHULTES (2012). Dots indicate known records outside the Mediterranean (OTTÓ 1980, ČEJKA et al. 2014, MIENIS 2015, RONSMANS \& VAN DEN NEUCKER 2016, this study) 

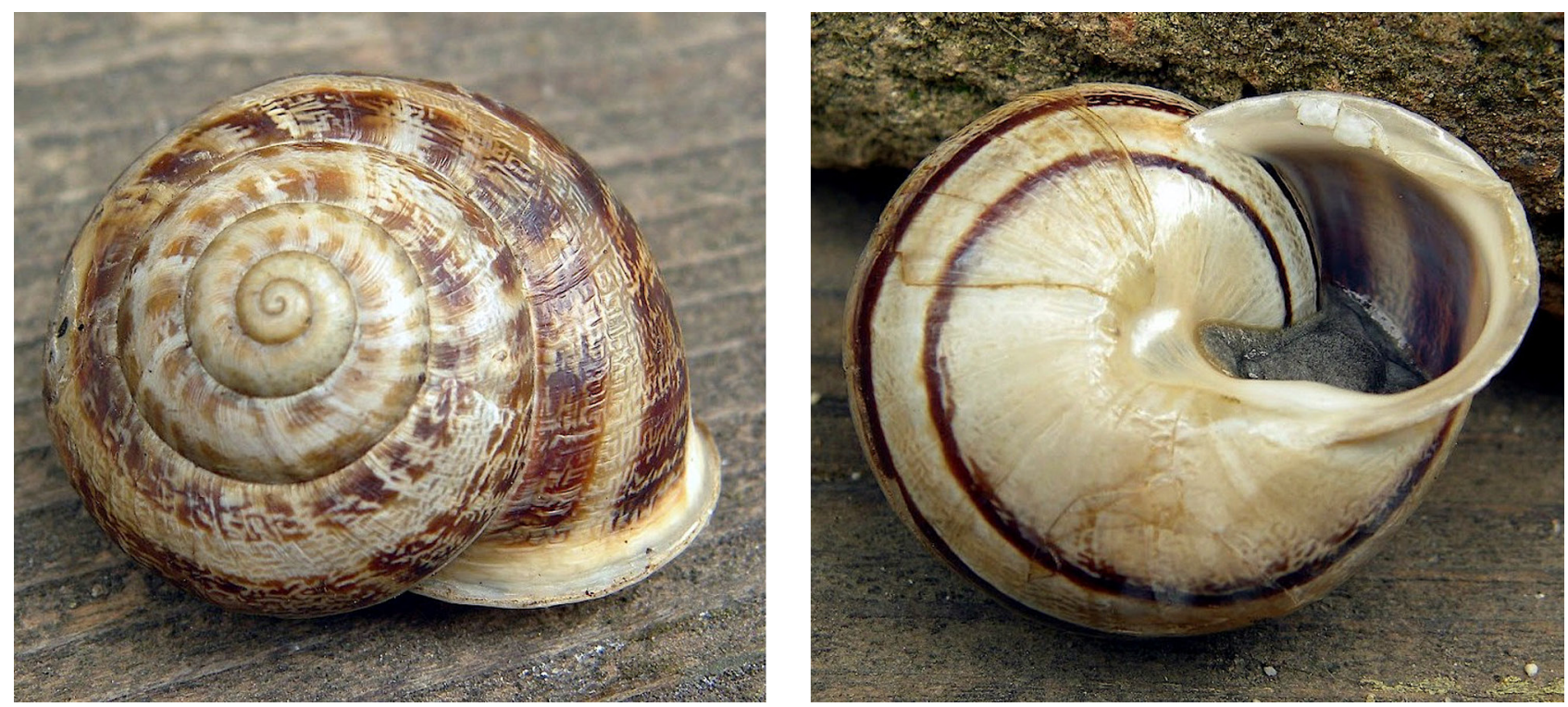

Fig. 2. Massylaea vermiculata found in Bratislava in June, 2019. Photo: T. ČEJKA

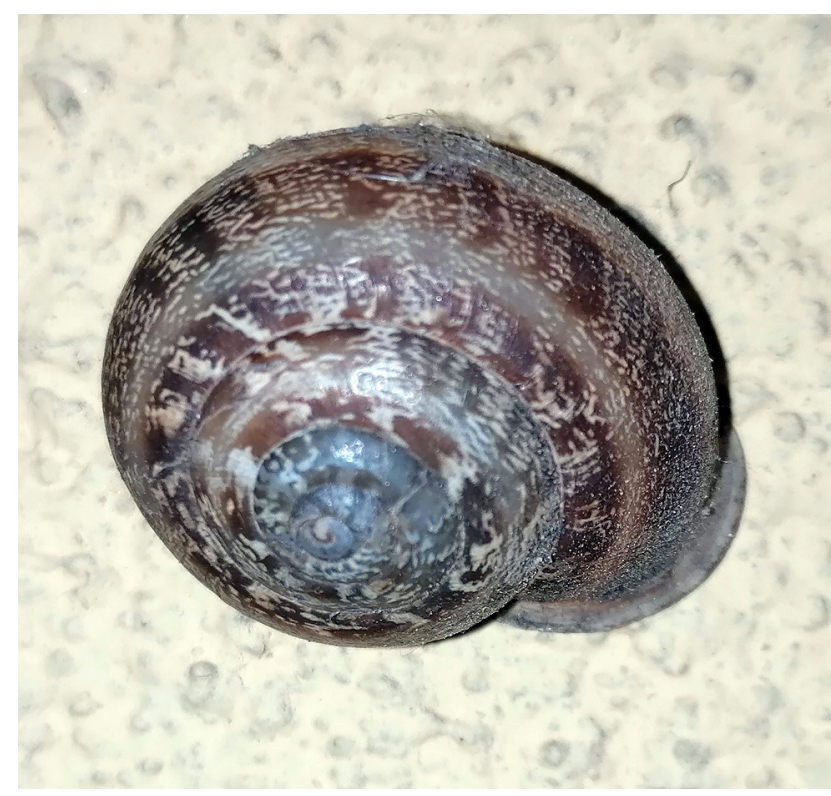

Fig. 3. Massylaea vermiculata found in Budapest in March, 2020 and uploaded to the www.fajbook.hu citizen science website. After a careful search, the specimen was re-found and captured two months later in May, 2020. Photo: JULIANNA KELEMEN

warm enough even during winter. No further information about that population was published subsequently, nor were any other live specimens reported in Hungary. The species was never reported from Austria, although Peter L. Reischütz found a live $M$. vermiculata on a lettuce in an Austrian supermarket decades ago (ALEXANDER REISCHÜTZ, pers. comm., 2020 May). In 2009, ČEJKA et al. (2014) found three live individuals of $M$. vermiculata in Cologne (West Germany). The species was introduced to a number of countries including the USA, Australia, Japan, South Africa, Egypt, Israel, Saudi Arabia, Jordan, and
Iran (see RONSMANS \& VAN DEN NEUCKER 2016 and references therein). CAPINHA et al. (2014) claimed that $M$. vermiculata was able to establish viable populations only in areas where climatic conditions were similar to or warmer and wetter than those of its native range. Later, MIENIS (2015), MIENIS et al. (2017) as well as RONSMANS \& VAN DEN NEUCKER (2016) reported on successful overwintering of introduced populations in Belgium and the Netherlands. This might be an indication that also Central European climatic conditions might be locally suitable for the overwintering of this species. In Budapest, the newly discovered specimen was found in the yard of a condominium suggesting that it arrived either with garden plants as a stowaway, or as a souvenir from a Mediterranean holiday. The fact that it was discovered in March suggests that it may have overwintered there. The observations of TURÓcI et al. (2020) provided useful insights regarding the rapid spread of introduced molluscs. They found two non-native slug species, Krynickillus melanocephalus Kaleniczenko, 1851 and Tandonia kusceri (H. Wagner, 1931), in single sites in Hungary. After the first confirmed site, they posted photos on Facebook with explanations on the slugs' morphology, asking citizen scientists to send them photos of similarly looking slugs. Even though some of the researchers knew of only a single site of each slug species, within a short time ca. 20 localities were recorded by citizen scientists, indicating that both species were already widespread in Hungary. Consequently, we cannot rule out the possibility that despite the small number of known Hungarian and Slovak sites, $M$. vermiculata may already be widespread in both countries. However, another research seems to suggest the contrary. During a similar Facebook inventory targeting the helicids Cornu aspersum (O. F. Müller, 1774), Helix lucorum Linnaeus, 1758 and Helix 
pomatia Linnaeus, 1758 in Budapest, we received photos and/or specimens of those three species from ca. 250 sites, along with reports of other helicid species not targeted by the Facebook post. Among the few hundred photos, none showed $M$. vermiculata. Furthermore, none of the cases reported here represented stable populations. H. lucorum and C. aspersum have been present in Budapest for no longer than 25 years. The former is restricted to the hilly Buda side, but is quite widespread and frequent there. The latter can be found practically everywhere, most records being from the plain Pest side (PÁlL-Gergely et al. 2019). Cornu aspersum is known to spread very rapidly and can survive in any kind of disturbed habitat. Massylaea vermiculata may be more similar to $\mathrm{H}$. lucorum, preferring walls and rather shady, more "delicate" places than $C$. aspersum. Thus, we expect that the spread of $M$. vermiculata would be rather localised, and its presence would be probably restricted to rather "good-looking" habitats, similarly to that of $H$. lucorum. In any case, targeted monitoring would be necessary to track the spread of $M$. vermiculata. More frequent appearance of new alien Mediterranean species can be due to the increase in long-distance trade and leisure activities. It is not surprising that many of the newly introduced species and/or populations are discovered in populated areas. These areas are more affected by unintentional and intentional introductions. Furthermore, they are more likely to provide suitable thermal conditions for these newcomers, as the temperature is usually higher in cities than in uninhabited areas, which is the well-known urban heat island effect (WILBY 2007). Eradication of potentially invasive species is suggested in the early

\section{REFERENCES}

Bouaziz-Yahiatene H., Pfarrer B., Medjdoub-BensaAd F., NEUBERT E. 2017. Revision of Massylaea Möllendorff, 1898 (Stylommatophora, Helicidae). ZooKeys 694: 109-133. https://doi.org/10.3897/zookeys.694.15001

CAPINHA C., RÖDder D., Pereira H. M., KAPPES H. 2014. Response of non-native European terrestrial gastropods to novel climates correlates with biogeographical and biological traits. Global Ecology and Biogeography 23: 857-866. https://doi.org/10.1111/geb.12176

ČEJKA T., HORSÁK M., JUŘIČKOVÁ L. 2014. A Mediterranean snail Eobania vermiculata (O. F. Müller, 1774) in NW Germany. Malacological Bulletin. Available online at: https://malbull.blogspot.com/2014/06/a-mediterranean-snail-eobania.html (accessed 15 May 2020).

CsÁNYI B., VARGA A. 2017. Behurcolt és invazív puhatestűek. Magyar Tudomány 2017/4: 419-425.

GenOVESI R., SCALERA S., BRUNEL D. R., SOlARZ W. 2010. Towards an early warning and information system for invasive alien species (IAS) threatening biodiversity stages of invasion, when populations are small and localised (GENOVESI et al. 2010). Therefore, all specimens captured in the Belgian population were killed (RONSMANS \& VAN DEN NEUCKER 2016). All three specimens reported here were captured and killed in ethanol in order to forestall the establishment any viable populations. The photos of the Hungarian specimen of $M$. vermiculata were discovered on a citizen science website, Fajbook.hu, which further emphasises the usefulness of such platforms for early detection and control of invasive species (FALK et al. 2016, MAISTRELLO et al. 2016, GRASON et al. 2018, VÉTEK et al. 2018, PÁLL-GERGELY et al. 2019, TURÓCI et al. 2020).

\section{ACKNOWLEDGEMENTS}

The citizen science website Fajbook.hu made it possible to discover the Hungarian site of $M$. vermiculata. Special thanks go to BENCE MÁTÉ and ÁDÁM GÓR for their technical assistance and to JULIANNA KELEMEN for allowing her discovery to be published. T. ČEJKA thanks Mr JÁN ČAPKA (Botanical garden, Bratislava) for providing the individual of the species from the horticultural facility Agapé, thanks also go to the owner of the Agapé agency Mr ANTON HIRGEL for the opportunity to survey the horticultural centre area, to EIKE NEUBERT (Natural History Museum of the Burgergemeinde Bern, Switzerland) for confirming the identification of the species, and to ALEXANDER REISCHÜTZ for the unpublished information on the Austrian occurrence. The survey has been partly supported by the Slovak Scientific Grant Agency (VEGA No.2/0079/18).

in Europe. European Environment Agency Technical Report 5: 1-52.

FAlK B. G., SNOW R. W., ReEd R. N. 2016. Prospects and limitations of citizen science in invasive species management: a case study with Burmese pythons in Everglades National Park. Southeastern Naturalist 15: 89-102. https://doi.org/10.1656/058.015.sp806

Grason E. W., MCDONALD P. S., AdAMs J., LiTlE K., APPlE J. K., PLEUS A. 2018. Citizen science program detects range expansion of the globally invasive European green crab in Washington State (USA). Management of Biological Invasions 9: 39-47. https://doi.org/10.3391/ mbi.2018.9.1.04

Maistrello L., Dioli P., Bariselli M., Mazzoli G. L., GIACALONE-FORINI I. 2016. Citizen science and early detection of invasive species: phenology of first occurrences of Halyomorpha halys in Southern Europe. Biological Invasions 18: 3109-3116. https://doi. org/10.1007/s10530-016-1217-z 
MIENIS H. K. 2015. Nogmaals Eobania vermiculata in Purmerend. Spirula 402: 15.

MienIS H. K., RITTNER O., VAISMAN S. 2017. Information concerning Eobania vermiculata, II. On the presence of extra-territorial material in the National Mollusc Collections in Israel (Mollusca, Gastropoda, Helicidae). Triton 35: 15-22.

OTTÓ L. 1980. Levél a szerkesztőnek: A Lipót községi termálfürdő puhatestủi. Soosiana 8: 9-10.

PÁll-Gergely B., Majoros G., Domokos T., Juhász A., Turóci A., BADACSONYI L., FeKETE J., AsAmi T. 2019. Realtime Social Networking Service rapidly reveals distributions of non-indigenous land snails in a European capital. Bioinvasions Records 8: 782-792. https://doi. org/10.3391/bir.2019.8.4.06

PeltanovÁ A., Petrusek A., KMENT P., JuŘičKovÁ L. 2012. A fast snail's pace: colonization of Central Europe by Mediterranean gastropods. Biological Invasions 14: 759-764. https://doi.org/10.1007/s10530-011-0121-9

RONSMANS J., VAN DEN NEUCKER T. 2016. A persistent population of the chocolate-band snail Eobania vermiculata (Gastropoda: Helicidae) in Belgium. Belgian Journal of Zoology 146: 66-68. https://doi.org/10.26496/ bjz.2016.41
TURÓCI Á., FeHÉr Z., KRÍZsIK V., PÁlL-Gergely B. 2020. Two new alien slugs, Krynickillus melanocephalus Kaleniczenko, 1851 and Tandonia kusceri (H. Wagner, 1931), are already widespread in Hungary. Acta Zoologica Academiae Scientiarum Hungaricae 66: 265282. https://doi.org/10.17109/AZH.66.3.265.2020

VÉteK G., KÁrolyi B., MÉszÁros Á., HoRVÁtH D., KORÁNYI D. 2018. The invasive brown marmorated stink bug (Halyomorpha halys) is now widespread in Hungary. Entomologia Generalis 38: 3-14. https://doi. org/10.1127/entomologia/2018/0631

WELTER-SCHULTES F. W. 2012. European non-marine molluscs, a guide for species identification. Planet Poster Editions, Göttingen.

WILBY R. L. 2007. A review of climate change impacts on the built environment. Built Environment 33: 31-45. https://doi.org/10.2148/benv.33.1.31

Received: June 10th, 2020

Revised: August 19th, 2020

Accepted: September 4th, 2020

Published on-line: October 9th, 2020 